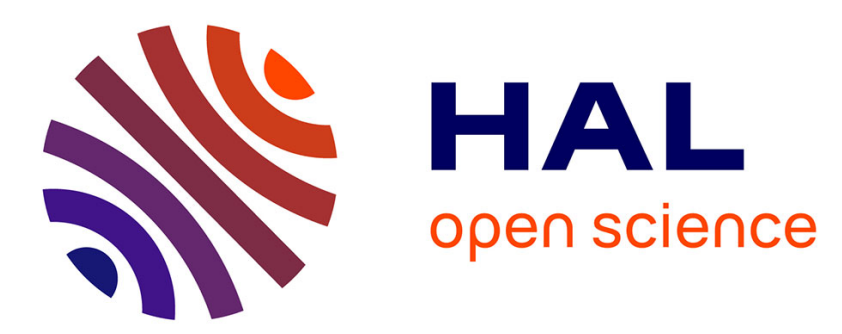

\title{
Green roof ageing or Isolatic Technosol's pedogenesis?
} Ryad Bouzouidja, Gustave Rousseau, Violaine Galzin, Rémy Claverie, David Lacroix, Geoffroy Séré

\section{To cite this version:}

Ryad Bouzouidja, Gustave Rousseau, Violaine Galzin, Rémy Claverie, David Lacroix, et al.. Green roof ageing or Isolatic Technosol's pedogenesis?. Journal of Soils and Sediments, 2018, 18 (2), pp.418425. 10.1007/s11368-016-1513-3 . hal-01520147

\section{HAL Id: hal-01520147 https://hal.univ-lorraine.fr/hal-01520147}

Submitted on 29 Aug 2017

HAL is a multi-disciplinary open access archive for the deposit and dissemination of scientific research documents, whether they are published or not. The documents may come from teaching and research institutions in France or abroad, or from public or private research centers.
L'archive ouverte pluridisciplinaire HAL, est destinée au dépôt et à la diffusion de documents scientifiques de niveau recherche, publiés ou non, émanant des établissements d'enseignement et de recherche français ou étrangers, des laboratoires publics ou privés. 


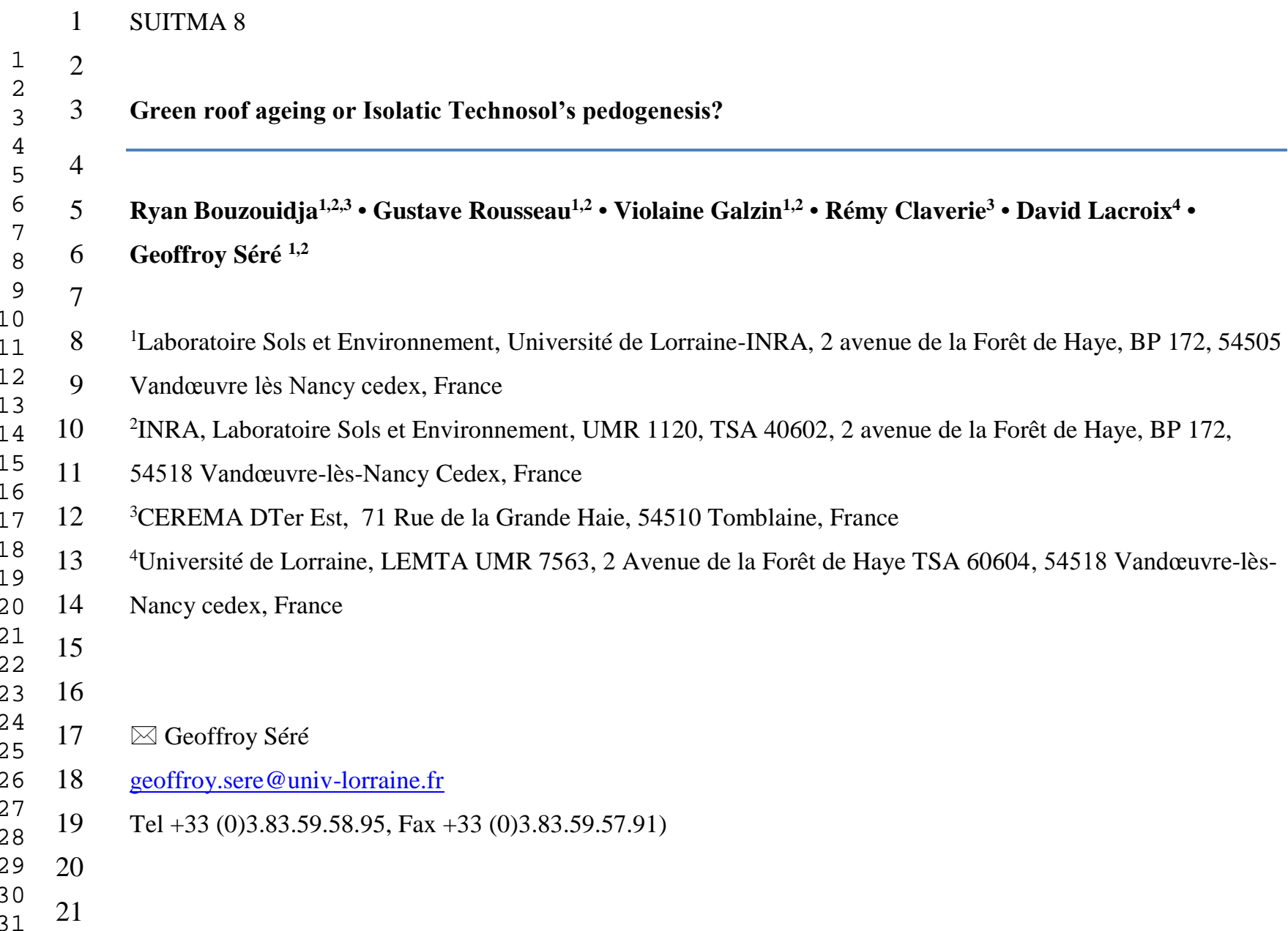

8 Laboratoire Sols et Environnement, Université de Lorraine-INRA, 2 avenue de la Forêt de Haye, BP 172, 54505

9 Vandœuvre lès Nancy cedex, France

10 '2INRA, Laboratoire Sols et Environnement, UMR 1120, TSA 40602, 2 avenue de la Forêt de Haye, BP 172,

1154518 Vandœuvre-lès-Nancy Cedex, France

$12{ }^{3}$ CEREMA DTer Est, 71 Rue de la Grande Haie, 54510 Tomblaine, France

13 ㄴniversité de Lorraine, LEMTA UMR 7563, 2 Avenue de la Forêt de Haye TSA 60604, 54518 Vandœuvre-lès-

14 Nancy cedex, France

15

$17 \bowtie$ Geoffroy Séré

18 geoffroy.sere@univ-lorraine.fr

$19 \mathrm{Tel}+33(0) 3.83 .59 .58 .95, \mathrm{Fax}+33(0) 3.83 .59 .57 .91)$ 


\section{Abstract}

Purpose: Green roofs (GR) offer a way to improve several ecosystem services in cities. However, the performances of GR are basically considered as steady over time whereas they are living media subject to ageing that are rarely managed by their owners. This study transposes a pedological approach to evaluate changes in GR physical structure and chemical composition over time.

Materials and methods: A full scale experimental plot with various vegetation cover was studied. An appropriate sampling of a four years substrate was implemented on the basis of observation. Then physical and chemical characterization were conducted and compared to results on the original substrate.

30 Results and discussion: The top sub-layer of the substrate contained a large amount of fine and short roots whereas the root density was much smaller in the lower layer of the substrate. There was a drastic drop of $3 \%$ of the organic carbon content between the initial substrate and the 4 years old substrate. On contrary the nitrogen concentration has increased of $0.4 \%$ during the same period. The total porosity decreased from $0.45 \mathrm{~cm}^{3} \mathrm{~cm}^{-3}$ to $0.38 \mathrm{~cm}^{3} \mathrm{~cm}^{-3}$. On the whole substrate the $<2 \mathrm{~mm}$ particles fraction was smaller after 4 years $(12.5 \%)$ than in the initial substrate $(18.2 \%)$ which was especially obvious in the upper horizon (9.5\%). Additionally, the monitored properties also varied significantly as a function of soil cover (sedum, moss and bare soil). Evidences of an early pedogenesis were highlighted.

38 Conclusions: In conclusion, the study demonstrated the effects of time, climate and vegetation on physical and chemical properties of green roofs. They are not only classified as Isolatic Technosols due to their composition 40 and implementation, they also exhibit one of the major characteristic of young Technosols: a fast and intense pedogenesis.

Keywords Green roof $\bullet$ Pedogenesis $\bullet$ Substrate $\bullet$ Temporal changes 


\section{Introduction}

Increasing use of green roofs (GR) on the top of the buildings of our cities rely on their acclaimed benefits regarding local climate and storm water regulation (Mentens et al. 2006; Alexandri and Jones 2008) as well as their contribution to urban biodiversity (MacIvor and Lundholm 2011). Such ecosystem services are progressively evaluated in a variety of situations and climates through scientific studies (Carter and Jackson, 2007; Moran and Smith, 2005). However, the performances of GR are basically considered as steady over time whereas they are living media subject to ageing that are rarely managed by their owners. Considering their composition - mixing of extracted and transported materials form natural origin such as pozzolana or peat and man-made products such as bricks and compost that all are defined as "artefacts" (IUSS 2014) - and the way they are implemented, green roofs clearly belong to the "Technosol" Soil Reference Group (IUSS 2014). Their properties are dominated by the technical origin of their parent materials. Moreover, their main attribute is clearly defined under the qualifier "isolatic: having, above technic hard material, above a geomembrane or above a continuous layer of artefacts starting $\leq 100 \mathrm{~cm}$ from the soil surface, soil material containing fine earth without any contact to other soil material (e.g. soils on roofs or in pots)" (IUSS 2014). We already proposed to classify them as Isolatic Technosol (Drainic, Folic, and Transportic) (Bouzouidja et al. 2016).

As Technosols, GR and especially their substrates are reactive media that can be submitted to an early and fast pedogenesis that lead to an evolution of their physical and chemical properties (Séré et al. 2010; Huot et al. 2015; Leguédois et al. 2016). However, actual results about GR evolution are controversial subjects. Evidences of the evolution with time of the chemical composition of different green roof substrates were demonstrated. However the observations are contrasted, as some observed a decrease with time of organic matter in the substrates (Emilsson et al. 2007), whereas others described an enrichment in both organic carbon and total nitrogen contents (Schrader and Boening 2006). Concerning physical characteristics, a study on a 5-years-old substrate showed that the water holding capacity has increased compared to a new one (Getter et al. 2007), whereas Mentens et al. (2006) evidenced the lack of influence of the age of the GR on its hydraulic behaviour. Very recent works focused on such a target as the highlighting of drastic evolution of GR's physical properties. De-Ville et al. (2015) interestingly described the fact that the upper layers of two different aged substrates have an increased number of finer particles whereas the lower part exhibited few changes. This increase was attributed, amongst other factors, to atmospheric particles deposition and weathering processes. They observed that the development of roots led to a leaching of organic constituents and a consequent local enrichment in organic matter. Finally, the authors also demonstrated a decrease of total porosity, with antagonistic results about the fine and the open porosities, considering one or the other substrate. As a consequence, De-Ville et al. (2015) estimated that such an evolution could influence green roof performances, especially as water regulation is concerned. These results are absolutely consistent with another study that suggested a decrease of the hydraulic performances of a GR due to an evolution of its physical organization (Bouzouidja et al. 2016). All of this work focuses on the substrate study that has most of time heterogeneous and diverse geographical origin. Consequently, the contradictory aspect of performance may be linked to this.

Thus, it appears that soil science is progressively transposing its methods to study physical and chemical properties of such an artificial medium as GR substrate. Beyond their WRB classification, do GR behave like soils? Are they submitted to a fast and intense early pedogenesis like other Technosols? The present work aims 
at: i) defining relevant sampling and measurement strategies to exhibit the evolution of an aged GR substrate over time ii) describing such transformations in terms of pedogenic processes.

\section{Materials and methods}

\subsection{Experimental site}

90 This work was based on an in situ experimental GR plot settled in Tomblaine (north-east of France, $48^{\circ} 40^{\prime} \mathrm{N}$ $916^{\circ} 13^{\prime} \mathrm{E}$, under temperate climate ). The local meso-climate is semi-oceanic with a continental degraded marked 92 influence, with an average annual precipitation of $763 \mathrm{~mm}$. The average external temperature is $10^{\circ} \mathrm{C}$ with high 93 amplitude of variations between summer and winter (Bouzouidja et al. 2013)

94 The green roof platform, built in July 2011, is placed above an approximately $6 \mathrm{~m}$ height flat roof building. The 95 overall GR surface area is $600 \mathrm{~m}^{2}, 40 \mathrm{~m}^{2}$ of which were studied for this work. (Figure 1). The substrate is a manmade porous medium composed of pozzolana (60\% of $3-6 \mathrm{~mm}$ particles and $20 \%$ of $7-15 \mathrm{~mm}$ particles) and organic parts (10\% of peat dust and $10 \%$ of maritime pine bark). The thickness of this layer is comprised between 7.5 and $9.5 \mathrm{~cm}$. Vegetation plants that were installed are classically: sedum album, sedum reflexumlarix, sedum reflexum germanium, sedum sexangulare, sedum floriferum (Bouzouidja et al. 2013). These plants do not exceed $10 \mathrm{~cm}$ in height. In this study, the changes of the GR was observed and monitored on one plot designed as Stock 40 .

\subsection{Sampling and in situ measurement strategy}

Two time steps were studied: original substrate (S0) and 4 years old substrate (S4). We based the sampling on the observation of the substrates vertical profiles and decided to split them into three sub-horizons: $0-2 \mathrm{~cm}, 2-5$ $\mathrm{cm}, 5-10 \mathrm{~cm}$. The soil cover was also taken into account by sampling on zones covered by sedums ( $\mathrm{S}$-sedum), by moss (S-moss) and bare soil (S-bare). Each soil cover was replicated three times.

The measurement of plant coverage was performed using three permanent quadrats $(1 \mathrm{~m} \times 1 \mathrm{~m})$ and the photographic method according Magill (1989) .

An observation of the roots distribution was realized on the aged GR on S-sedum. The used method was based on in situ mapping protocol described by Tardieu and Manichon (1986). The measurement was conducted on three replicates, on a surface of $900 \mathrm{~cm}^{2}$. For each sample a regular grid $(0.5 \mathrm{~cm} \times 0.5 \mathrm{~cm}$ cells $)$ is chosen, the root occurrence is defined by a coloured cell and its absence by an empty cell.

\subsection{Substrate characterization}

The samples have been air-dried during 48h. They have been sieved at 5,2 and $0.2 \mathrm{~mm}$. All fractions have been collected, weighted and characterized for total carbon (Ctot) and total nitrogen (Ntot) (vario Micro cube, Elementar).

Bulk density has been measured thanks to core-sampling. The soil water retention characteristics, i.e. volumetric water content at field capacity $\left(\theta_{\mathrm{fc}}\right)$ and permanent wilting point $\left(\theta_{\mathrm{pwp}}\right)$, were determined on a pressure plate apparatus at $0.33 \mathrm{kPa}$ and $15 \mathrm{kPa}$ respectively (Bruand et al. 1996). The solid density was then measured with a helium pycnometer (Quantachrome UltraPyc 1200 ) based on NF P18-554. Total porosity $(\delta)$ was then calculated after (Eq. 1). Macroporosity (Mp), mesoporosity (mp) and microporosity ( $\mu$ p) were estimated after the previous measurements. 


$$
\delta=1-\frac{\rho_{a}}{\rho_{r}}
$$

Where $\rho_{\mathrm{a}}$ and $\rho_{\mathrm{r}}$ are respectively apparent and real soil density $\left(\mathrm{kg} \mathrm{m}^{-3}\right)$.

Jim and Peng (2012) described that the soil water potential is largely influenced by the poral architecture. The authors determined different porosities class for green roof soils: i) the micropores have equivalent diameters < $0.2 \mu \mathrm{m}$, ii) the mesopores have equivalent diameters comprised between 0.2 and $60 \mu \mathrm{m}$ and iii) the macropores have equivalent diameters that are $>60 \mu \mathrm{m}$. According to Peverill et al. (1999), the relationship between porosity and soil moisture explained by water content at field capacity $\left(\theta_{\mathrm{FC}}\right)$, permanent wilting point $\left(\theta_{\mathrm{PWP}}\right)$ can be determined as:

$$
\begin{gathered}
\mathrm{Mp}=\delta-\theta_{\mathrm{FC}} \\
\mathrm{mp}=\theta_{\mathrm{FC}}-\theta_{\mathrm{PWP}} \\
\mu \mathrm{p}=\theta_{\mathrm{PWP}}
\end{gathered}
$$

\section{Results and discussion}

\subsection{Vegetation development}

The development of vegetation on the different plots was fast during the spring and summer of the first year (2011) and reached its plateau (between 90 and $95 \%$ ) in August 2011 (Figure 2). The most present sedum plants were of different species, mainly: S. Spurium, S. Album and S. Floriferum with respectively 39, 26 and $21 \%$.The plant diversity exhibited small changes that were not significant over time. During this time, mosses have developed themselves punctually, without being measured. Our observations are coherent with those from Nicholson (2004). They make a survey of the vegetation of a GR located in London area ten years after establishment; they found that mosses were also frequent in the more open areas and north-facing orientation.

The Figure 3 presents three replicates of root profiles on S-sedum. Two distinct sub-layers are clearly visible. The top sub-layer $(0-5 \mathrm{~cm})$ contains a large amount of roots $(31.2 \% \pm 4.3 \%)$. Oppositely the root density is much smaller $(8.4 \% \pm 4.7 \%)$ in the lower layer $(5-9 \mathrm{~cm})$.

MacIvor and Lundholm (2011) reported that vegetation roots development causes the substrate restructuring. In this work, the upper part of the substrate was highly colonized by roots which led to an increase in fresh organic matter. Such a result is consistent with the evolution of physical parameters highlighted by Schrader and Boening (2006).

\subsection{Organic matter and nitrogen dynamics}

There was a drastic decrease of the organic carbon content between the initial substrate ([Ctot $\left.]_{\mathrm{s} 0}=5.09 \%\right)$ and the average 4 years old substrate $\left([\mathrm{Ctot}]_{\mathrm{s} 4}=2.10 \% \pm 0.65 \%\right)$ (Figure 4). Concentrations also varied significantly as a function of soil cover, especially at the surface $(0-2 \mathrm{~cm})$. The higher content was under the sedum cover $\left([\mathrm{Ctot}]_{\mathrm{S4-sedum}}=2.87 \% \pm 0.44 \%\right)$, then the moss cover $\left([\mathrm{Ctot}]_{\mathrm{S} 4 \text {-moss }}=2.62 \% \pm 0.53 \%\right)$ and the bare soil at last $\left([\mathrm{Ctot}]_{\text {s4-bare soil }}=1.98 \% \pm 0.57 \%\right)$. Changes in total carbon concentrations profiles were also observed with a decrease from the surface to the depth for both sedum and moss covers (Figure 4). Oppositely, a small increase was observed under bare soil for the $2-5 \mathrm{~cm}$ sub-horizon compared to the surface.

To explain the global decrease of organic matter over time, two hypotheses could be formulated that are supported by a previous work (Chow et al. 2006). Indeed, peat materials are formed under specific conditions, 
very different from the GR environment. It appears especially that the temperature variations and the wet-dry cycle effects strongly enhance the organic carbon mineralization. Nevertheless, maximum mineralization rate that was measured under controlled conditions was around $1 \mathrm{~g} \mathrm{~kg}^{-1}$ over two months (Chow et al. 2006). Over 4 years, considering a constant intensity (which is unrealistic) it would correspond to a decrease of $2.4 \%$, which is below the observed $3 \%$ mentioned before. As a consequence, additional organic carbon dissolution and vertical transfer probably happened in the GR following mechanisms that are described by Chow et al. (2006) and Vodyanitskii (2015). Besides, some further consideration will be assessed below about particles transfer. Apart from that, it can be suggested that the surface enrichment is basically due to and also depending on the vegetation development.

In a very different way, nitrogen concentration increased over time between the initial substrate $\left([\mathrm{Ntot}]_{\mathrm{S} 0}=\right.$ $0.13 \%)$ and the average 4 years old substrate $\left([\mathrm{Ntot}]_{\mathrm{S} 4}=0.54 \% \pm 0.20 \%\right)$ (Figure 4). Similar trends as for carbon were observed: higher concentrations under vegetation (even if the nitrogen content was higher under moss than under sedum) and decreasing concentrations from the surface to the bottom part of the substrates.

Organic matter mineralization is a logical explanation to explain nitrogen increase over time. Consistent observations have been made, especially by repeatedly measuring higher nitrogen concentrations in runoff water from green roofs when compared to control roofs (Van Seters et al. 2007; Hathaway et al. 2008; Retzlaff et al. 2008). Apart from the mineralization, another mechanism could explain such phenomenon: the deposition of nitrogen oxides coming from airborne (Oberndorfer et al. 2007).

\subsection{Fine particles eluviation}

In all situations, the $<2 \mathrm{~mm}$ particles fraction were smaller after 4 years $(12.5 \% \pm 2.9 \%)$ than in the initial substrate (18.2\%) (Figure 4). Potential vertical transfer of fine particles leading to an accumulation on the geotextile and an eluviation through the drainage layer has already been described (Schwager et al. 2015). Despite that fact, the solid density was almost the same for S0 $\left(2.84 \mathrm{~g} \mathrm{~cm}^{-3}\right)$ than for S4 $\left(2.85 \mathrm{~g} \mathrm{~cm}^{-3} \pm 0.03 \mathrm{~g} \mathrm{~cm}^{-}\right.$ ${ }^{3}$ ), suggesting an equal loss of all kind of substrate's constituents.

A very clear pattern, if not statistically tested, was observed under all soil covers on the aged GR. Indeed, there was an enrichment of fine particles $(<2 \mathrm{~mm})$ in the second sub-horizons $(2-5 \mathrm{~cm})(14.6 \% \pm 2.3 \%)$ compared to the top sub-horizons $(9.5 \% \pm 2.1 \%)$ and the bottom horizons $(13.9 \% \pm 0.5 \%)$ (Figure 4). The eluviation process was the most pronounced in the bare soil, whereas it was the least visible under moss cover. Under sedum cover, the particles transfer was intermediate. The most probable assumption is that the fine particles were eluviated from the surface by the rain. The presence of vegetation would limit the intensity of the process by covering the soil surface and slowing down the velocity of the water flux.

The novelty in our approach was the strategic sampling in three sub-horizons of the thick substrate layer. Indeed, we performed previous tests, before the profile observations, by dividing only into two layers and only small grain size's differences were visible as indicated by De-Ville et al. (2015).

\subsection{Poral architecture}

The total porosity of S0 $\left(0.45 \mathrm{~cm}^{3} \mathrm{~cm}^{-3}\right)$ was higher than for S4 $\left(0.38 \mathrm{~cm}^{3} \mathrm{~cm}^{-3} \pm 0.02 \mathrm{~cm}^{3} \mathrm{~cm}^{-3}\right)$ (Figure 5). The moisture at the field capacity indicated that the macroporosity remained almost constant over time ( $\mathrm{S} 0=0.26$ $\mathrm{cm}^{3} \mathrm{~cm}^{-3} ; \mathrm{S} 4=0.24 \mathrm{~cm}^{3} \mathrm{~cm}^{-3}$. The microporosity (calculated after the volumetric water content at permanent 
wilting point) increased in $\mathrm{S} 4\left(0.12 \mathrm{~cm}^{3} \mathrm{~cm}^{-3}\right)$ compared to $\mathrm{S} 0\left(0.07 \mathrm{~cm}^{3} \mathrm{~cm}^{-3}\right)$. The decrease in total porosity was mainly explained by the drastic decrease of mesoporosity between $\mathrm{S} 0\left(0.11 \mathrm{~cm}^{3} \mathrm{~cm}^{-3}\right)$ and $\mathrm{S} 4$. Considering the size of the sampling core and the shallow depth of the substrates, it was not possible to study the effect of depth on such parameters.

These measurements indicated modifications of the structure and consequently an evolution of the association between the particles of the substrates. Furthermore, such results suggested not only a small decrease of the water holding capacity of the substrate with time as already highlighted (Bouzouidja et al. 2016), but also a major decrease of the available water for plants in the aged substrate. This would require confirmation by observation of the vegetation behaviour during drought events.

\subsection{Early pedogenic evolution}

Various changes over time of physical and chemical properties have been noted in the GR substrates. Our results are consistent with the existing literature cited above, but the soil science methods - observation / adapted sampling / measurement - added an explicit identification and quantification of the involved processes. Thus, such pedogenic processes as organic matter transfer, transformation and degradation, fine particles eluviation, and structure evolution have been highlighted in Technosols that are analogous to what happened in natural soils. But, in accordance to what Leguédois et al. (2016) described, most of the Technosols are known to be submitted to a notably quick evolution. This is due to the disequilibrium between their parent materials and the environmental forcing factors that lead to an internal response that induced a high-energy state of such artificial media (Séré et al. 2010). This is the case for GR substrates that mix different particulate materials from various origins, with much contrasted properties.

The preliminary results currently available, including the one presented here, suggest that there are concomitant processes that happened with a significant intensity shortly after the substrate implementation. However, very little is presently known about i) the kinetic of such processes, ii) the influence of external factors (i.e. climate, vegetation), iii) the influence of internal factors (i.e. nature and ratio of the parent materials) that would require further investigations.

\section{Conclusions}

The study of an aged GR substrate led to the evidences of drastic transformations of both physical and chemical properties compared to the original substrate. The results show that over 4 years, the organic carbon has decreased from $5.0 \%$ to $2.10 \%$ and that the nitrogen concentration has increased from $0.13 \%$ to $0.54 \%$. At the same time, a loss of fine particles was also observed. The implementation of an adequate sampling protocol into representative sub-horizons based on the observation and pedological measurements enabled an explicit quantification of active soil forming processes. Indeed, organic matter transformation and fine particles eluviation, structure evolution have been reported that depend on both the vegetation cover or the depth. The acquisition of a vertical organization of the GR substrate over time is now suggested. In addition to the Isolatic Technosol definition, such criteria promoted the idea to consider GR as urban soils. As Technosols, GR are submitted to fast and significant changes that can affect their performances. Further researches are needed either to assess more precisely such evolution and to develop new technical solutions for GR conception and management. 


\section{References}

Alexandri E, Jones P (2008) Temperature decreases in an urban canyon due to green walls and green roofs in diverse climates. Build Environ 43:480 - 493. doi: 10.1016/j.buildenv.2006.10.055

Bouzouidja R, Claverie R, Sere G, Lacroix D (2013) Characterization of the thermo-hydric functioning of in situ green roof. Houille Blanche 5:62 - 69. doi: 10.1051/lhb/2013044

Bouzouidja R, Séré G, Claverie R, et al (2016) Green roof ageing: quantifying the impact of substrate evolution on hydraulic performances. Submitt. Ecol. Eng.

Bruand A, Cousin I, Nicoullaud B, et al (1996) Backscattered electron scanning images of soil porosity for analyzing soil compaction around roots. Soil Sci Soc Am J 60:895-901.

Carter T, Jackson CR (2007) Vegetated roofs for stormwater management at multiple spatial scales. Landsc Urban Plan 80:84 - 94. doi: 10.1016/j.landurbplan.2006.06.005

Chow E, Meldrum CJ, Crooks R, et al (2006) An updated mutation spectrum in an Australian series of PJS patients provides further evidence for only one gene locus. Clin Genet 409-414.

De-Ville S, Menon M, Stovin V (2015) Using X-ray microtomography to identify physical changes in green roof substrates as a result of ageing. In: The Annual Postgraduate Research Student Conference. Sheffield, UK, pp 8-13

Emilsson T, Berndtsson JC, Mattsson JE, Rolf K (2007) Effect of using conventional and controlled release fertiliser on nutrient runoff from various vegetated roof systems. Ecol Eng 29:260 - 271. doi: 10.1016/j.ecoleng.2006.01.001

Getter L, Rowe B, Anderson A (2007) Quantifying the effect of slope on extensive green roof stormwater retention. Ecol Eng 31:225-231.

Hathaway A, Hunt W, Jennings G (2008) A field study of green roof hydrologic and water quality performance. $37-44$.

Huot H, Simonnot M-O, Morel JL (2015) Pedogenetic Trends in Soils Formed in Technogenic Parent Materials.

IUSS WG (2014) International soil classification system for naming soils and creating legends for soil maps. WRBWorld Reference Base for Soil Resources 2014, FAO, Rome

Jim CY, Peng LLH (2012) Substrate moisture effect on water balance and thermal regime of a tropical extensive green roof. Ecol Eng 47:9 - 23. doi: 10.1016/j.ecoleng.2012.06.020

Leguédois S, Séré G, Auclerc A, et al (2016) Modelling pedogenesis of Technosols, Geoderma 262, 199-212. Geoderma 199-212.

MacIvor JS, Lundholm J (2011) Performance evaluation of native plants suited to extensive green roof conditions in a maritime climate. Ecol Eng 37:407-417.

Magill AW (1989) Monitoring environmental change with color slides.

Mentens J, Raes D, Hermy M (2006) Green roofs as a tool for solving the rainwater runoff problem in the urbanized 21 Itextsuperscriptst century? Landsc Urban Plan 77:217-226. doi: 10.1016/j.landurbanplan.2005.02.010

Moran W A an Hunt, Smith J (2005) Green Roof Hydrologic and Water Quality Performance from Two Field Sites in North Carolina. Manag Watersheds Hum Nat Impacts 1-12. doi: 10.1061/40763(178)99

Nicholson B (2004) CUE Building, Horniman Museum: Botanical survey. London 
Oberndorfer E, Lundholm J, Bass B, et al (2007) Green Roofs as Urban Ecosystems: Ecological Structures, 3282 Functions, and Services. BioScience 823-833.

Peverill KI, Sparrow LA, Reuter DJ (1999) Soil Analysis: An Interpretation Manual. CSIRO Publishing

Retzlaff W, Ebbs S, Alsup S, et al (2008) Evaluation of the Thermal Benefits of Green Roof Systems. In: Proceedings of the 6th Annual Greening Rooftops for Sustainable Communities Conference. Baltimore, MD, p 12

Schrader S, Boening M (2006) Soil formation on green roofs and its contribution to urban biodiversity with emphasis on Collembolans. Pedobiologia 50:347-356.

Schwager J, Schaal L, Simonnot M-O, et al (2015) Emission of trace elements and retention of $\mathrm{Cu}$ and $\mathrm{Zn}$ by mineral and organic materials used in green roofs. J Soils Sediments 15:1789-1801. doi: 10.1007/s11368-014-0962-9

Séré G, Schwartz C, Ouvrard S, et al (2010) Early pedogenic evolution of constructed Technosol. J Soils Sediments 10:1246-1254.

Tardieu F, Manichon H (1986) Caractérisation en tant que capteur d'eau de l'enracinement du maïs en parcelle cultivée. Agronomie 6:345-354.

Van Seters T, Rocha L, Mac Millan G (2007) Evaluation of the runoff quantity and quality performance of an extensive green roof in Toronto. Minneapolis, MN 2007,

Vodyanitskii YN (2015) Organic matter of urban soils. Eurasian Soil Sci 48:802-811. 
1

2

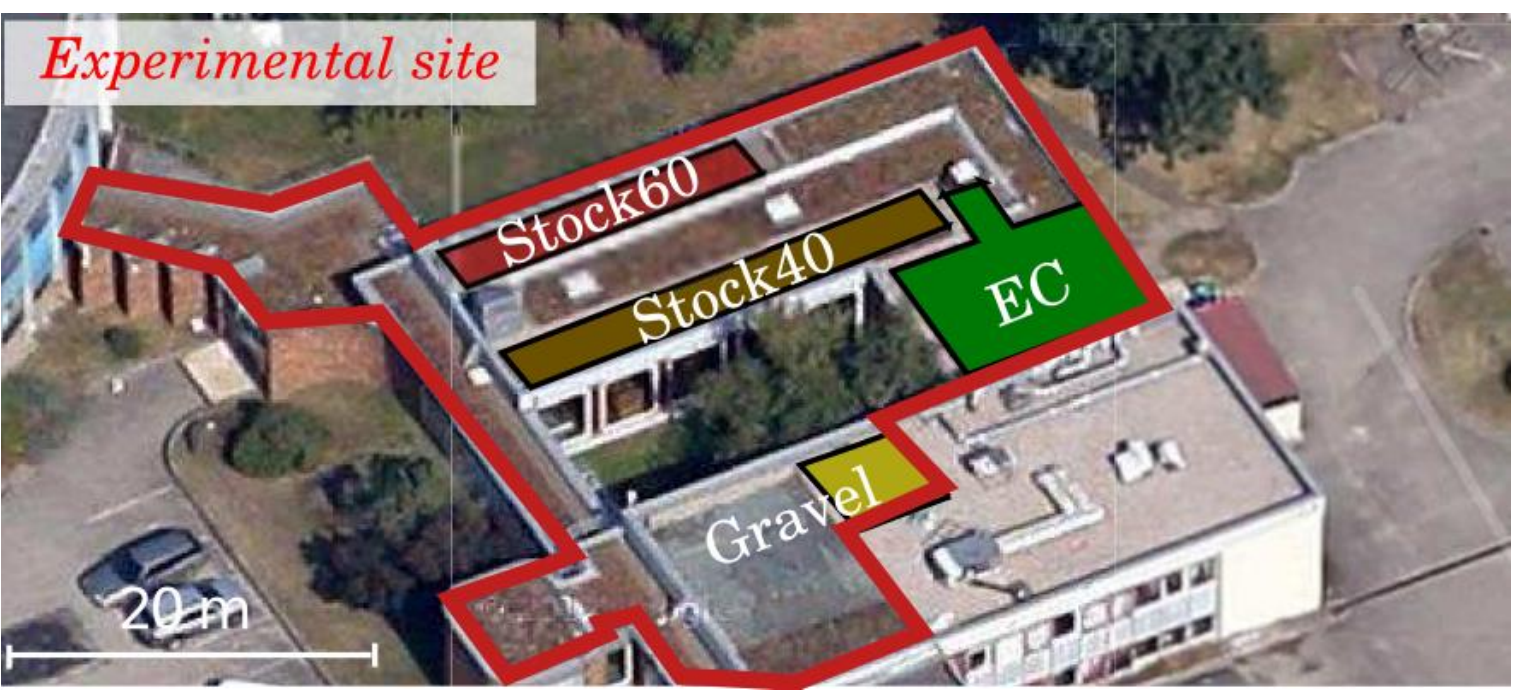

Figure 1: Overview of the experimental platform, comprising four green roof plots including Stock40 
1

2

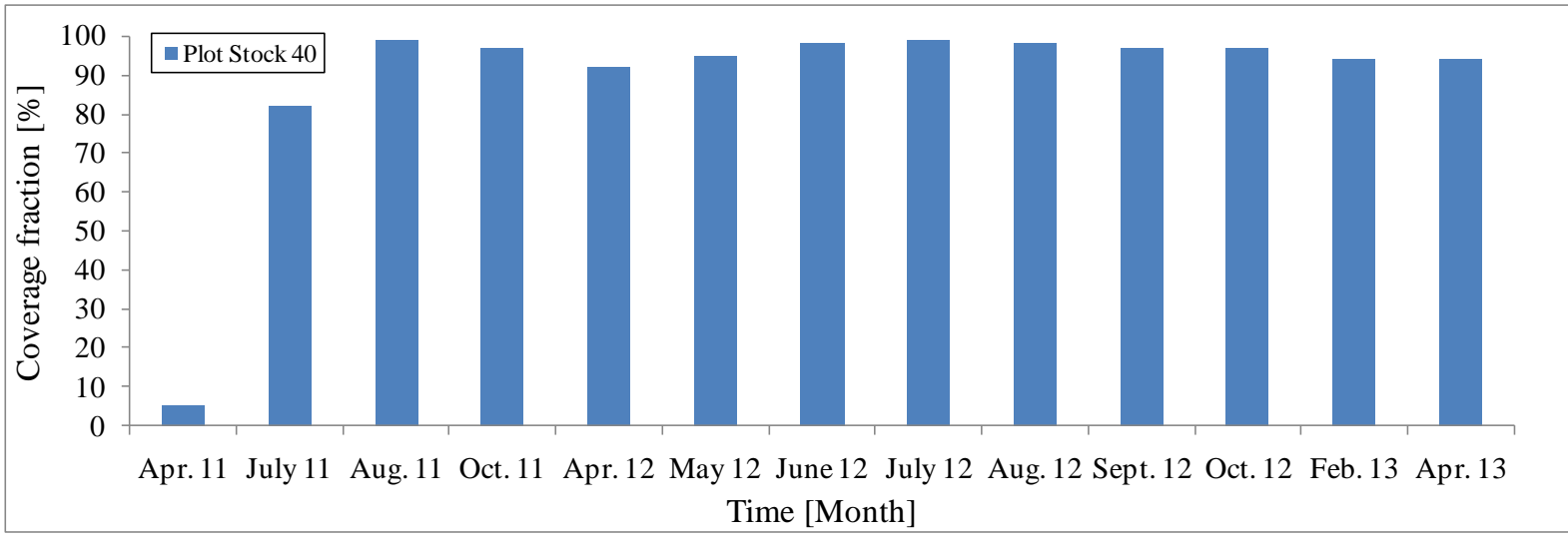

Figure 2: Evolution of coverage fraction of vegetation for the plot Stock40 between April 2011 and April 2013 


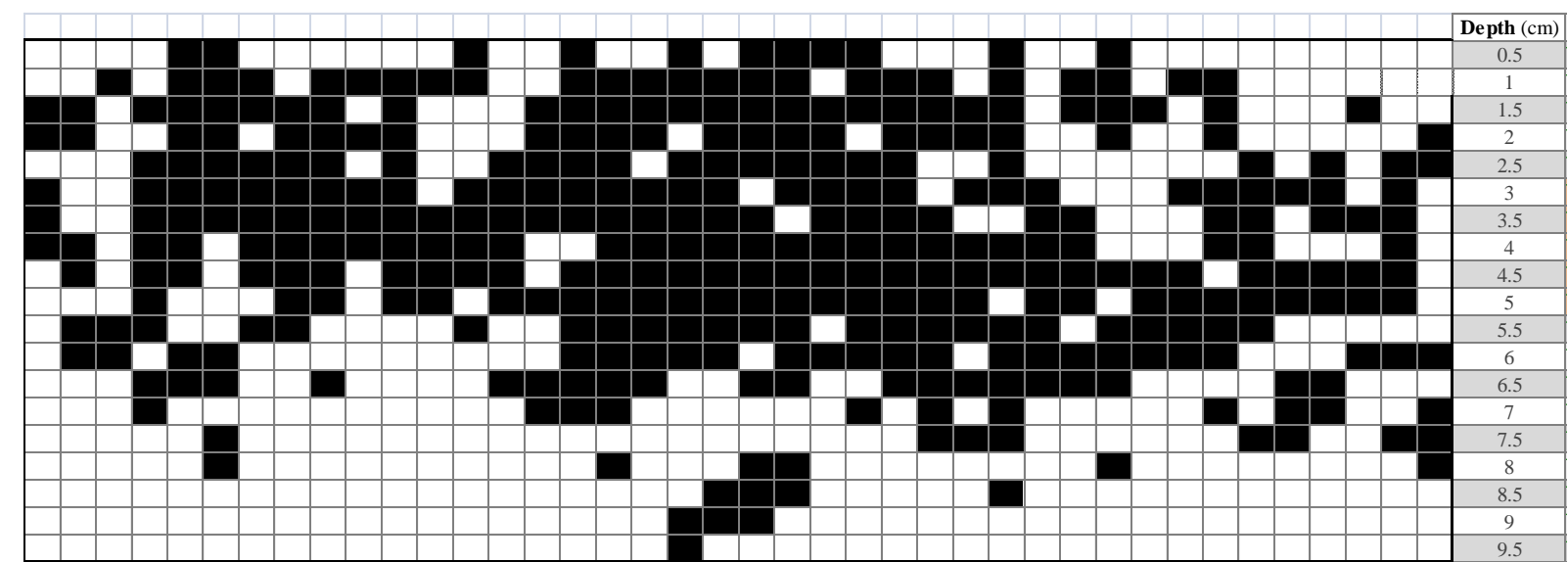

(a)

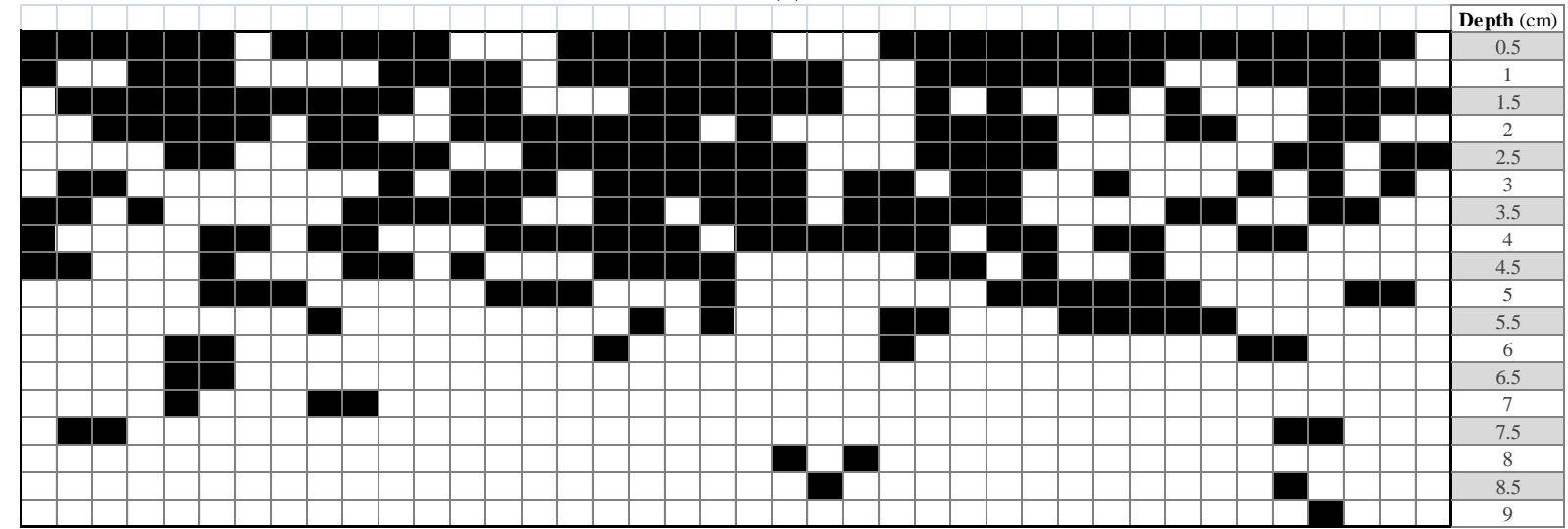

(b)

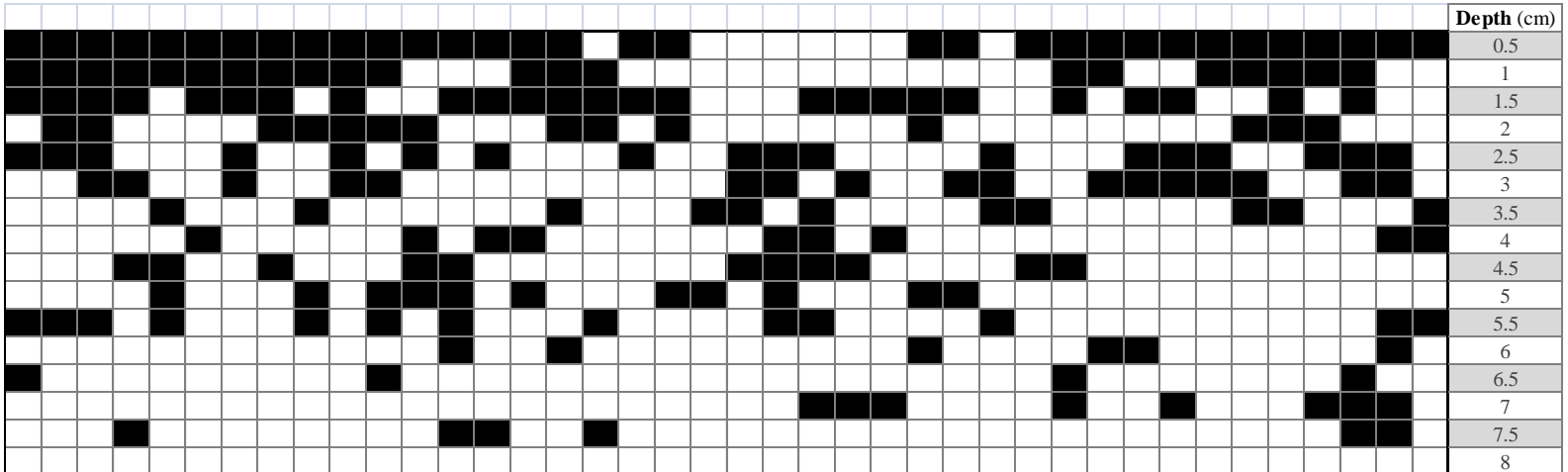

(c)

Figure 3: Root distribution profiles extracted from three samples of the S4 substrate on S-sedum, Black and White square are designed respectively as roots occurrence and voids. 

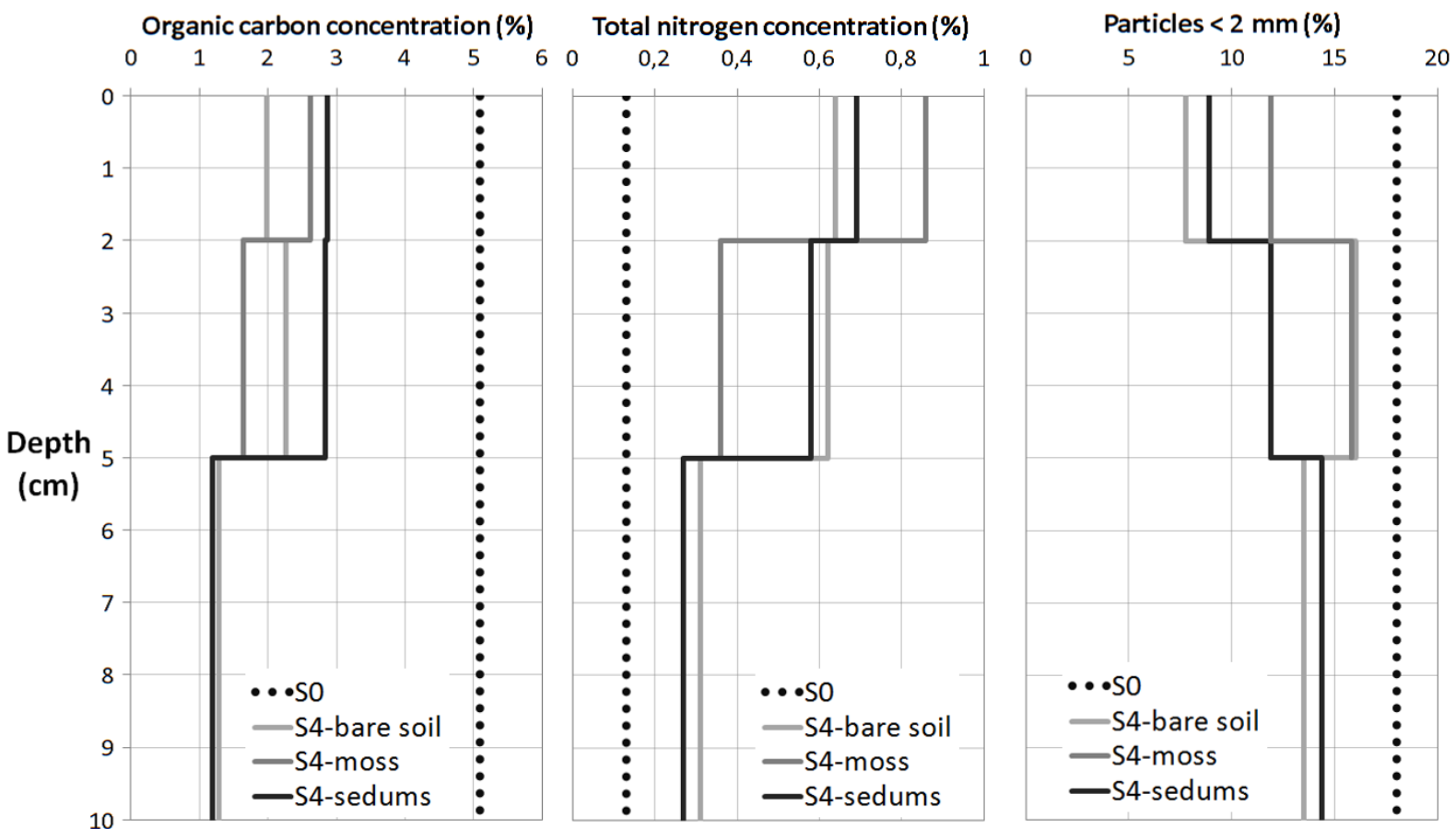

Figure 4: Evolution with depth of the fine particles, the organic carbon concentration and the total nitrogen concentration in the initial (SO) and 4 years aged substrates over different soil cover (bare soil, sedums and moss) 


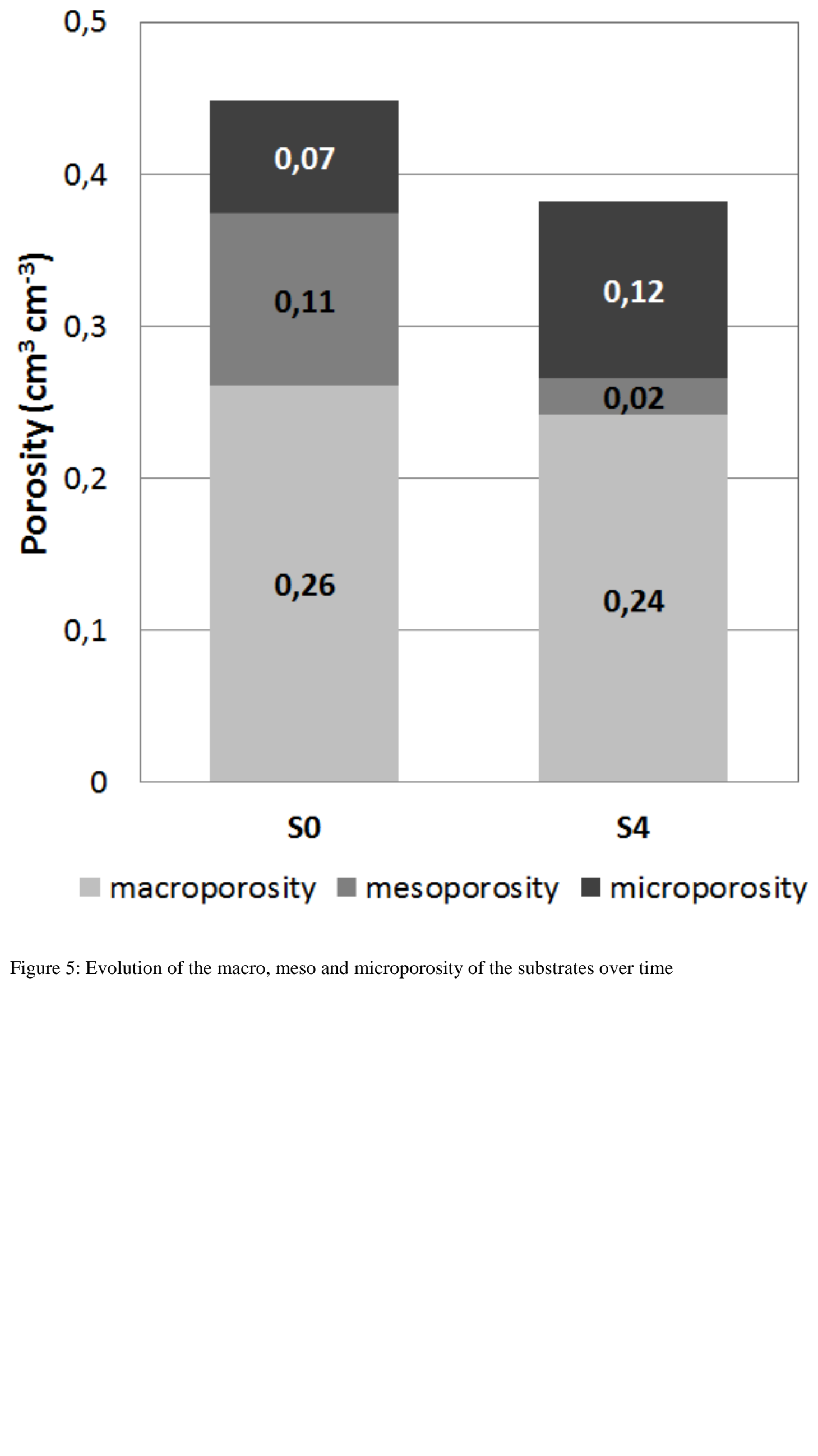

